\title{
Current Livelihood Condition of and Futurity of Tea Farming for Marginal Small Tea Farm Holders (MSTH) of Sri Lanka: Case Study From Badulla and Matara District
}

\author{
Indika R. Palihakkara ${ }^{1,2}$, Abrar J. Mohammed ${ }^{2} \&$ Makoto Inoue $^{2}$ \\ ${ }^{1}$ Faculty of Agriculture, University of Ruhuna, Sri Lanka \\ ${ }^{2}$ Graduate School of Agricultural and Life Sciences, The University of Tokyo, Japan \\ Correspondence: Palihakkara R. Indika, Graduate School of Agricultural and Life Sciences, The University of \\ Tokyo, Tokyo, Japan. Tel: 81-03-5841-7509. E-mail: irpalihakkara@gmail.com.
}

\author{
Received: November 14, 2014 Accepted: November 27, $2014 \quad$ Online Published: December 11, 2014 \\ doi:10.5539/enrr.v5n1p11 \\ URL: http://dx.doi.org/10.5539/enrr.v5n1p11
}

\begin{abstract}
With an area of 120,955 ha, Small Tea Farm Holders (STH) constitute about forty percent of the total tea land area of Sri Lanka. In addition to possessing small tea land area, portion of small holders face another serious problem, low productivity of the tea land. With the aim of filling the knowledge gap on the livelihood of Marginal Small Tea Farm Holders (MSTH) and guide future policies and other interventions based on existing realities, this research analyzes the livelihood of MSTH in Badulla and Matara district using Sustainable Livelihood (SL) Framework and discusses futurity of tea production for MSTHs. Since land is the most limiting factor for their livelihood, the MSTH were first divided into four land categories ranging from very small to large holder. Then, their livelihood capital was measured using the five livelihood capitals, i.e., natural, human, social, physical and financial. The result showed inconsistent relationship between land size of MSTH and other capitals such as number of trees planted and income from tea production. The district with smaller average land size (Matara) and the very small and small land holders within district were found to generate more income from tea reduction. Improving human capital through education was also found to contribute negatively toward labor contribution for tea production. Between districts, weather and elevation, two forms of natural capital which are mostly neglected in rural studies using SL approach, were found to play important role in determining outcome from tea based livelihood. Overall, however, majority of the farmers are in the view that tea generates low benefit and should look for other alternatives. Considering this, possibility of other livelihood activities such as conversion of the marginal tea land to fuelwood planation should be considered. This, in addition to improving farmers' livelihood through enhanced income from their land, will also contribute for overcoming the ongoing shortage of fuelwood in Sri Lanka while also improving the environmental service from the MSTHs' land.
\end{abstract}

Key words: marginal tea plantations, smallholders, land use conversion, Tea Small Holding Development Authority

\section{Introduction}

Tea (Camellia sinensis L.) has been playing an important role in economic development of Sri Lanka from its inception as a plantation production system during the European colonial expansion period in the middle of 19th century by Sir James Taylor in 1867 (Ganewatta, 2000; TRI, 2006).Initially, tea was cultivated in central highlands of Sri Lanka. With growing demand in international markets for this cash crop, the tea area expanded further into untouched forest as well as coffee plantations in central Sri Lanka, and finally to Uva ( includes Badulla district) and low lands of south western Sri Lanka (includes Matara District). The current extent of tea plantations of the country accounts for $11 \%$ of total agricultural land area that is about 212,700 ha (Ministry of Plantation Industries, 2012), which is managed as either a private estates, government estates or Small Tea farm Holders (STH).

Small Tea farm Holders (STH) are defined as farmers with tea plantations area of less than 20.2 hectares (50 acres) and without their own processing facilities. This definition was operationally established during the 1972 and 1976 land reform laws when all the tea farms larger than 50 acres were expropriated (Deepananda, 2009). Currently, there are about $390,346 \mathrm{STH}$ with a total extent of tea farm area of 120,955 ha representing higher percentage tea 
land extent out of three plantation management categories (TSHDA, 2012). The number of small holders in the country increased by $70 \%$ for the previous 10 year before the last censes taken in 2005 (TSHDA, 2012).

In addition to having small tea land area, portion of the STH face another serious problem, or low productivity of the tea land. These low productive farmlands are characterized as marginal tea land. Marginal tea land are tea production lands with a yield below the national average tea yield which is $1615 \mathrm{~kg} / \mathrm{ha}$ (Ministry of Plantation Industries, 2012). With Sri Lanka's tea industry claiming the highest cost of production among other competition countries (Ganewatta et al., 2000), Marginal Small Tea Holders' (MSTH) ' interest in tea based livelihood as well as land development is being further reduced. For example, tea bushes belonging to most of the tea plantations were planted more than 40 to 60 years ago (Dissanayake, 2013). Moreover, according to censes taken in 2005, about 7310 hectares of the small holder plantations were abandoned (TSHDA, 2012).

Totally or partially abandonment of MSTH's tea plantations create many problems. In addition to the socio-economic drawbacks it case to the farmers, it also contributes for environmental problems of the area as well as to the country. Sri Lanka is facing environmental problems such as irregular rainfall, drying up of natural streams, soil erosion and associated loss of fertility etc., especially in tea producing areas (Mungai, 2004), Therefore, understanding the prevailing reality of marginal tea small holders is important to tackle the socio-economic as well as environmental consequences of existing tea-based land use systems (FAO, 2012). By utilizing the livelihood capital approach, this research is aimed at exploring the current livelihood condition of STH farmers and the futurity of tea farming. Specifically, it explores natural, financial, human, physical and social capital of the small holders and their perspective towards tea farm production.

The remaining part of the paper is organized as follows. The next section elaborates on the analytical framework utilized for this paper followed by the research method section. In the result and discussion section, the current livelihood condition of the MSTH farmers, measured in terms of the five livelihood capital, as well as their perception towards tea based livelihood strategy is presented and discussed. The pearls of the paper as well as possible remedies to improve the existing situation of MSTH farmers is finally detailed in conclusion and policy recommendation section.

\section{Analytical Framework}

During the last decades, with the renewed international commitment to poverty reduction together with the ever increasing environmental concern, there have been significant theoretical and practical advances in the way poverty-environment linkages are considered. Rural poverty has been accepted as both a major cause and result of degraded soils, vegetation, forests, water and natural habitats (DFID 2000; Mohammed, 2014). Although poor people in developing countries are particularly dependent on natural resources and its ecosystem services for their livelihoods, they live in areas of high ecological vulnerability and relatively low levels of resource productivity (Mohammed \& Inoue, 2013; Mohammed \& Inoue, 2014). On the other hand, rapid deforestation and biodiversity losses are depriving people of valuable forest resources, such as fuel wood, food and medicine. Soil degradation is a major threat to the livelihoods of 1 billion people, mostly the poor who are more likely to live in degraded or fragile areas (Baumann, 2002). Considering such linkage between nature resource degradation and poverty, understanding the livelihood of poor living in degraded environment is vital for designing sustainable resource management or prescribe alternatives.

The Sustainable Livelihoods Approach (SLA) emerged partly as a result of this rethinking of poverty-environment linkages and has since become a driving force in its evolution (Brocklesby \& Fisher, 2003). One of the key attribute of SLA is the livelihood capital of household as capital serve as vehicles for making a living, making living meaningful and challenging the structures under which one makes a living (Bebbington, 1999).The livelihood framework identifies five core capital which sometimes are called livelihood building blocks upon which livelihoods are built. These are natural, social, human, physical and financial capital (Scoones, 1998).

Natural capital is the natural resource stocks including plants, trees, soil, water, land with its characteristics etc. while financial capital refers to monetary capital bases such as incomes, savings and other (Sherbinin et al., 2008). The skills, knowledge, ability to labor etc. are the human capital. Physical capital includes productive assets held by the household like vehicles, tools, oxen etc. (Scoones, 1998; Sherbinin et al., 2008). The social capital include networks, social claim, social relations, affiliations, association upon which people draw when pursing different livelihood strategies requiring individual or coordinated action (Scoones, 1998).

Improving capital assets is a primary strategy for improving rural people's livelihood from a given livelihoods strategy. Rural poor usual require a range of capitals to pursue their strategies. Core concepts for an understanding of local decision-making to follow a given livelihood strategy, therefore, is the notions of asset substitution and 
trade-offs. Such understanding enables framing of strategic questions for development planning (Baumann, 2002). It particularly helps understand local people perceptions towards a given livelihood strategy (Figure 1).

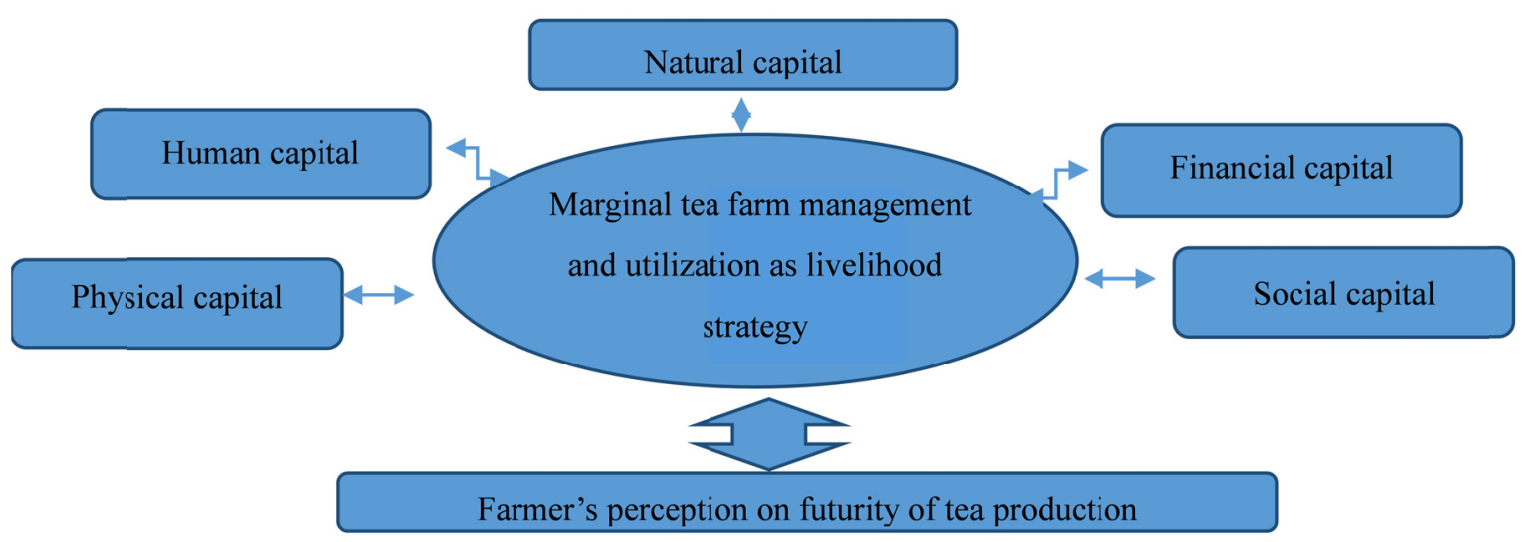

Figure 1. Analytical framework of the study

\section{Research Method}

\subsection{Study Site Description}

The study is conducted in Matara and Badulla districts which represent lowland and highland tea plantation of the country respectively. After preliminary discussion with staffs from Tea Small Holding Development Authority (TSHDA) regional officers of the two districts, MSTH from Urubokka, Haliella, Lunugala, and Ella TSHDA sub divisions were selected for the study as they have relatively large number of MSTH.

Urubokka is a TSHDA sub division in Matara district, while Haliella, Lunugala, Ella are TSHDA sub divisions in Badulla district. Urubokkais situated, North East border of Matara district, adjoining Hambantota and Rathnapura districts. Haliella is situated south western part of Badulla district while Lunugala and Ella are found in the border of Badulla district adjoining to Moneragala district (Figure 2).
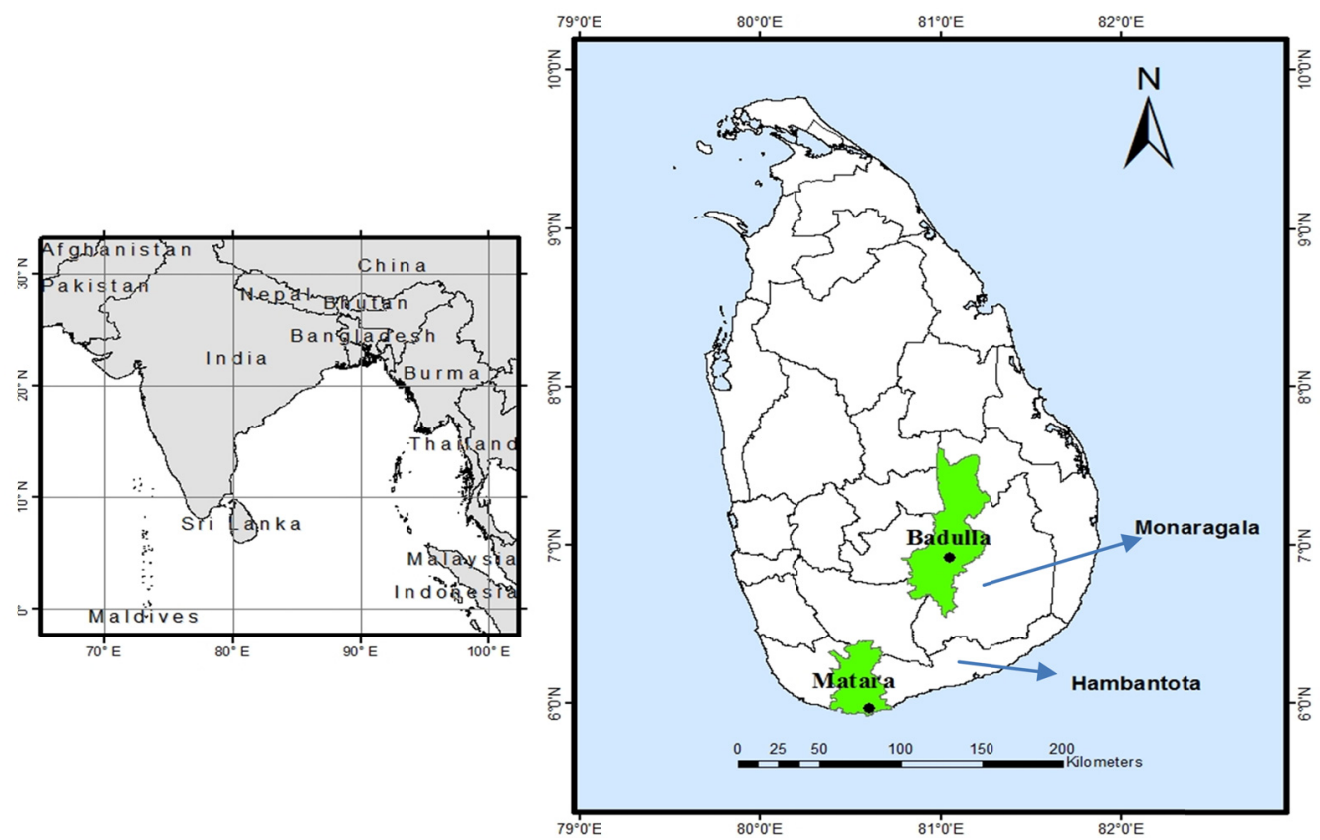

Figure 2. Location of Sri Lanka and the study sites Matara and Badull districts in Sri Lanka 


\subsection{Data Collection and Analysis}

Data collection was conducted in two stages. In the first stage, review of archival records such as field records as well as reconnaissance survey of the research site together with TSHDA officer in charge of the area and chairman of tea farmer organizations was undertaken. By using the archival record review, a total of 648 and 177 MSTH were identified from Matara and Badulla district respectively. After consultation with TSHDA officers, a total 50 MSTH for Matara and 31 MSTH for Badulla were randomly selected for data collection.

Based on land size classification of TSHDA, the selected farmers were categorized into four land class, i.e., very small land holders (VSLH) ( $<1 \mathrm{ha})$, small land holders (SLH) (1-2 ha), middle land holders (MLH) (2-3 ha), large land holders (LLH) (3-20 ha) (Table 1). Direct observation was conducted to MSTHs' plantation and land conditions such as slope, maturation, type of management. The visit was also used as an opportunity to get familiarized with the village and the farmers.

Table 1. Sampled MSTH categorized according to their land size

\begin{tabular}{llcc}
\hline \multirow{2}{*}{ Category } & Land extent & \multicolumn{2}{c}{ Number of farmers } \\
\cline { 3 - 4 } & & Matara & Badulla \\
\hline Very small land holders (VSLH) & Less than 1hectare & 32 & 8 \\
Small land holders & Between 1 and 2 hectare & 8 & 8 \\
Middle land holders (MLH) & Between 2 and 3 hectare & 5 & 5 \\
Large land holders (LLH) & Between 3 and 20 hectare & 5 & 10 \\
\hline
\end{tabular}

In the second stage, detailed quantitative and qualitative data were collected using interviews and archival records. A pre-tested structured and semi structured questionnaire was used to collect data on the five capitals of MSTH as per the analytical framework developed. The collected data includes information on human capital (number of family members, their contribution to the plantation, number of formal trainings, and experience on tea industry); natural capital (plantation extent, \% slope of the plantation land), Physical capital (possession of bike, motorbike, car, tractor); social capital (organization membership, linkage with external actors) and financial capital (farmer's income, green leaf productivity, income from crops other than tea) of the respondents. The data that requires farmers opinion such as their way of evaluating the plantations and, their opinion about futurity tea based livelihood was measured using a Likert scale ranging from $1=$ strongly disagree to $5=$ strongly agree. Qualitative information was collected by using key informant interviews and focus group discussions. Two group discussions were conducted, one in each district. Information was written down and cross-checked by reading them for the attendant/ respondents. The overall situation of tea planting, the problems they are facing as well as reason for farmers keeping uncultivated lands in their plantations were among the topic discussed during group discussion. The data was collected from beginning of July to end of August, 2013.

For analyzing family members' contribution to the plantation, rational scoring weight method was utilized (Jayamannna et al., 2002). Five selected activities, i.e. harvesting or tea plucking; weed management; shade tree management; fertilizer application, and other routine work such as, pest and disease control, maintenance of drains; were identified from previous works (Herath et al., 2009). Rationality of giving weight for each category was decided by the importance of each work. For example, tea harvesting claim $60 \%$ of the total green leaf production cost (Wijerathne et al., 2007) therefore, highest marks were allocated for harvesting. Slope angle of the plantations was calculated using the equation: $\mathrm{v}=\sin -1(\mathrm{~h} / \mathrm{l})$, where $\mathrm{v}$ is the slope angle, $\mathrm{h}$ is the measured height, and 1 the length along the slope. The length (1) was fixed at two meters for ease of calculations (Yang et al., 1997). For the other data, deceptive statistics and One-way ANOVA was conducted using SAS software to find out averages as well as statistical significances.

\section{Result and Discussion}

\subsection{MSTHs' Livelihood Capitals}

\subsubsection{Natural Capital}

In Matara, large proportion of the randomly sampled households belong to the VSLH category which has an average land area of 0.7 ha. In Badulla, on the other hand, most of the farmers are from the LLH category with an average land holding of 15.9 ha. In addition, the average land size of farmers in the first category is smaller in Matara compared to Badulla (Table 2). These may imply that the Badulla district is relatively well endowed in 
terms of the most important natural capital, i.e. farmland. The reason for this disparity can be traced back to the origin of current land tenure system of the two regions. In Badulla district, tea plantation was established during the British colonial era with large scale tea plantations (Wenzlhuemer, 2008; De Silva, 1981). After the independence, government of Sri Lanka introduce new land reform act in 1972 declaring that individual farmer can hold up to $20 \mathrm{ha}(50 \mathrm{ac})$ land and the rest were acquired and managed as government property. These 20 ha plantations with the time were further divided into smaller portions among the family members (Samaraweera, 1982). In the case of Matara District, however, small holder tea plantations were popularized after the independence with smaller land extents using other agricultural lands or clearing forest lands (De Silva, 1981).

While limitation of the slope of moderately suitable farmland recommended by TRI for Matara is in between $25 \%$ to $70 \%$, and Badulla is in between $25 \%$ to $55 \%$, actual average slope ranges from $48 \%-53 \%$ in Matara and from $49 \%-61 \%$ in Badulla. Farmers belong to MLH category with an average land area of 2.4 and 2.1 have the highest percentage slope at 53\%, and 61\%, in Matara and Badulla respectively (Table 2). The slope of all categories of both districts are in the upper levels of moderately suitable lands of TRI's land suitability classification for tea except for MLH in Badulla that is in sever category with a slope of $61 \%$. In general, however, the percentage slopes were not significantly different between the districts and among the four land categories in both districts.

Results on percentage of uncultivated land has showed that LLH category of the Badulla, which represented 32\% of the sampled farmers had the largest uncultivated land proportion at $30 \%$. Highest uncultivated land percentages were also observed in the SLH and LLH of Matara which is equal to $22.2 \%$. Overall, the difference in percentage of uncultivated land was significant between VSLH and LLH at $\mathrm{p}<0.1$ level. The relatively high percentage of uncultivated land from LLH mean that increase in large size may not guarantee improve in livelihood for this farm holds.

Another important capital for the tea growers is shade trees. Well maintaining shade trees provides not only shade for tea, but also a cheap source of firewood to meet energy requirements, timber, and nutrients for the soil in which tea bushes grow and reduce soil erosion. Since Sri Lanka has no oil or natural gas reserves, biomass from shade trees and other sources is of central importance to the overall energy supply of the country as identified by Forestry Sector Master Plan-Sri Lanka (FSMP, 1995).

Table 2. Natural capital of MSTH in the two districts

\begin{tabular}{lcccccccc}
\hline \multirow{2}{*}{ Natural \& bio-physical capital } & \multicolumn{4}{c}{ Matara District } & \multicolumn{3}{c}{ Badulla District } \\
\cline { 2 - 9 } & VSLH & SLH & MLH & LLH & VSLH & SLH & MLH & LLH \\
\hline Farm size (ha) & 0.7 & 1.3 & 2.4 & 13.7 & 0.8 & 1.3 & 2.1 & 15.9 \\
\% uncultivated & 11 & 22 & 13 & 22 & 15 & 6 & 7 & 30 \\
\% Slope & 48 & 48 & 53 & 49 & 49 & 54 & 61 & 52 \\
Number of tree & 1806 & 202 & 861 & 476 & 459 & 309 & 848 & 1484 \\
(high shade, medium shade) & $(178,1628)$ & $(42,160)$ & $(141,720)$ & $(26,450)$ & $(119,340)$ & $(104,205)(193,655)$ & $(384,1100)$ \\
location & \multicolumn{4}{c}{ Low elevation } \\
weather & \multicolumn{3}{c}{ Higher temperature } & \multicolumn{7}{c}{ Low temperature } \\
\hline
\end{tabular}

Interestingly, the result showed that VSLH farmers in Matara have the highest average number of trees, or 1806 trees of which 178 are high shade trees. In Badulla district, however, LLH has higher average number of trees (Table 2). In addition to providing shade, these trees have vital importance for the farmers. Usually, pollarding and periodic lopping of high and medium shade respectively are practiced to ascertain the optimal shade levels of $10-40 \%$. In addition, when the tree life span is over, it is removed from the plantation and replanted. For example, the average life span of Gravillea and Albizia is 30 and 12 years respectively. These pollarded and lopped materials as well as the entire trees that have been removed after finishing their life span are used for fuel wood. Such wood/fuel wood production from non-forest tree resources is highly significant in the Sri Lankan context. It is vital especially for tea growers to minimize the fuelwood shortage they commonly face. Due to fuelwood shortage, for example, the price of Gliricidia, increased to Rs 1500 per cubic meter at present from Rs 1000 per cubic meter two years ago (TRI Sri Lanka, 2012). In addition to fuelwood, these trees also provide diverse goods for the framers: from providing shade to and mulch for tea plantation, to providing edible food, 
medicine, fuelwood and timber to local people. Gliricidia sepiumis the dominant species in both district followed by Milia azedarach, Albizzia moluccana and Calliandra calothrysus, Erythrina lithosperma in Matara and Badulla respectively.

The last two major natural capital and the most determinant in terms of affecting the productivity as well as income of tea production are elevation and weather. Matara belong to low elevation wet zone of Sri Lanka with higher temperature. On the other hand, Badulla is located in high to mid elevation zone of Sri Lanka with relatively low temperature. Due to this higher temperature, Matara tea yield /unit area is higher with higher number of harvesting rounds per year than Badulla (Wijerathna, .2007). In addition, low elevation of Matara gives its green leaf higher price than mid and higher elevation tea leaf of Badulla (Sri Lanka tea board 2014).

\subsubsection{Financial Capital}

Financial capital of the farmers, which is measured by income from four major sources, i.e., from tea, other agriculture products (other than tea ), salary /pension/rental of property other than tea plantation and income from non-regular labor work in Sri Lankan Rupees(Rs) per celender year is presented in Table 3. Compared to Badulla, tea was found to contribute to major portion of the income in Matara. This is despite Badulla having comparatively large tea farmland than Matara. Moreover, the percentage of farmers having tea as the only income source were high for Matara with $43 \%, 50 \%, 80 \%, 40 \%$ from VSLH to LLH respectively. Tea income was found to be relatively less important in Badulla where salary/pension/ renting contributed the major source of income.

Table 3. Financial capital of MSTH in the two districts (Rs/year)

\begin{tabular}{llcccccccc}
\hline Category & \multicolumn{9}{c}{ Matara District } \\
& & Tea crop & Agriculture & Salary/ Pension/ Rent & Labor & Tea crop & Agriculture & Salary/ Pension/ Rent & Labor \\
\hline \multirow{2}{*}{ VSLH } & amount & $57471(45)$ & $17800(14)$ & $46908(37)$ & $4333(3)$ & $54462(27)$ & $16133(8)$ & $126000(64)$ & $2000(1)$ \\
& $\%$ & $43 *$ & 43 & 34 & 9 & $38^{*}$ & 38 & 38 & 12.5 \\
\multirow{2}{*}{ SLH } & amount & $54336(52)$ & $21000(20)$ & $30000(28)$ & $0(0)$ & $59276(32)$ & $26766(14)$ & $100800(54)$ & $0(0)$ \\
& $\%$ & $50 *$ & 37 & 13 & 0 & $50 *$ & 38 & 25 & 0 \\
MLH & amount & $73419(31)$ & $8000(3)$ & $156000(66)$ & $0(0)$ & $36572(23)$ & $14400(9)$ & $111000(68)$ & $0(0)$ \\
& $\%$ & $80 *$ & 20 & 20 & 0 & $0 *$ & 20 & 80 & 0 \\
LLH & amount & $28023(8)$ & $75000(21)$ & $259992(71)$ & $0(0)$ & $26681(14)$ & $14800(8)$ & $144000(78)$ & $0(0)$ \\
& $\%$ Farmers & $40 *$ & 20 & 60 & 0 & $30 *$ & 30 & 50 & 0 \\
\hline
\end{tabular}

*Indicates \%farmers getting income only from tea.

Especially LLH farmers, despite the expectation due to their large land, got only $14 \%$ of their income from tea with $78 \%$ of it coming from salary and pension. Labor work was found to be important income source only for the VSLH farmers (Table 4). This probably is because the labor force of relatively large land holders utilized their time and energy within their plantation. Overall, the total income from tea land seemed to be irrespective of the total land area of the farmers with small and middle land area holders generating much income than the farmers with large land holding.

\subsubsection{Human Capital}

For effective management of MSTH farmland and get good income, farmer's individual performances as well as their group work is vital. Hence number of family members and their labor contribution for tea planting, experience on tea farming, formal training received and their level of education play an important role (TSHDA Sri Lanka 2008). As shown in Table 5, the average number of family members ranged from 2.8 for MLH of Matara to 4.4 of VSLH in Badulla. Badulla district average number of family members is always above 4 for all categories. This is larger than the 2011 average household size of Sri Lanka which is 3.9. 
Table 4. Human capital of MSTH

\begin{tabular}{|c|c|c|c|c|c|c|c|c|}
\hline \multirow[t]{2}{*}{ Human capital } & \multicolumn{4}{|c|}{ Matara District } & \multicolumn{4}{|c|}{ Badulla District } \\
\hline & VSLH & SLH & MLH & LLH & VSLH & SLH & MLH & LLH \\
\hline No of family members & 4.3 & 4.4 & 2.8 & 3 & 4.4 & 4 & 4.2 & 4 \\
\hline Score/FM contribution & 7 & 7.6 & 1.3 & 0.5 & 6.4 & 5.4 & 3.2 & 0.1 \\
\hline Experience/ tea farming (Number of Years) & 30 & 26 & 40 & 43 & 49 & 52 & 53 & 57 \\
\hline No of formal training (Total trainings) & 1.4 & 2.3 & 6.8 & 9.2 & 2 & 1.1 & 1.6 & 3.7 \\
\hline Farmer Education (Number of years in formal education) & 6.5 & 7.6 & 13.8 & 13.6 & 8.4 & 10.9 & 9.6 & 12.9 \\
\hline
\end{tabular}

Table 5. Social capital of MSTH (Average. Number of members in social organizations)

\begin{tabular}{lccccccccc}
\hline \multirow{2}{*}{ Social organizations } & \multicolumn{4}{c}{ Matara District } & \multicolumn{4}{c}{ Badulla District } \\
\cline { 2 - 10 } & VSLH & SLH & MLH & LLH & VSLH & SLH & MLH & LLH \\
\hline TSHDA & 1 & 1 & 1 & 1 & 1 & 1 & 1 & 0.8 \\
Government supported & 0.5 & 0.3 & 1 & 0.7 & 0.25 & 0.25 & 0.4 & 0.5 \\
Local autonomous & 0.2 & 0.1 & 0.2 & 0.6 & 0 & 0.4 & 0.4 & 0.4 \\
NGO supported & 0.2 & 0.1 & 0 & 0.2 & 0 & 0 & 0 & 0 \\
\hline
\end{tabular}

Family member contribution decreased with the increasing land size, the lowest being for MLH and LLH of Matara. The reason for this, according to respondents, is that household members in MLH \& LLH have higher social recognition and education levels which made them reluctant to contribute for assisting their parents in the tea farm works. Their argument also supported by data on education level (Table 4). The presence of leaches (blood sucking small creature) in the tea farm that is said to be responsible for black scare in their skin was another justification for the educated youth to be unwilling to help their family. Such scars will make them easily recognized by other fellows that they are working in tea plantations which, for them, is socially degrading.

Experience in tea production for the two district varied from 26 for SLH of Matara to 57 for LLH of Badulla. Overall, Badulla district farmers have more experience than Matara farmers in all 4 categories (Table 4). The main reason for this is Badulla farmers either inherited or purchased the plantations under the Land Reform Act introduced in 1972 and with most of them having working experience with tea either on their own plantations or plantations managed by the British companies. While in Matara, majority of small holder farmers in the Matara District established in late 1970s and early 1980s after establishment of TSHDA and introduction of open economy system to Sri Lanka in 1977 (TSHDA 2012).

The education level of family members is good for both districts. Although there is not as such significant inter-district difference in education level, the intra district distribution was found to be quite different. Unlike Badulla, farmer's education level is higher at for MLH and LLH (13.8 and 13.6 respectively) and was significantly higher than VSLH and SLH which have 6.5 and 7.6 respectively. The possible reason for this is number of schools functioning in the Badulla by large scale tea plantations which established in the colonial period. Number of formal training received, however, is significantly higher for Matara than Badulla as well as for large holders compared to small holders except for VSLH of Badulla. (Note): To calculate score of FM contribution, rational scoring weight method was used

\subsubsection{Social Capital}

Owing to the labor intensive nature of Tea farming, MSTH can acquiring more benefits by working collectively and forming groups or networks that can be recalled when labor is demanded. This is quite advantageous even if there are opportunity costs such as time allocated to participate in meetings, payments needed for membership etc (Barrett 2001). In this study site, four types of societies were identified: TSHDA, Organization with government support and involvement, autonomous local organization formed and maintain by the local people, and NGO supported organization. MSTH from all land categories in both districts were found to belong to TSHDA (Table 5). Next to TSHDA, farmers were found to be more affiliated to government supported organization than autonomous organization and NGO supported ones. The more interest in local autonomy organization over NGO supported one is due to the diverse goods and services provided by the former. The roles 
of these local organizations are providing temporally constructing materials, cooking utensils, financial loans and labor during special social occasions such as funeral and wedding. In Matara few farmers attached to organization under type 3, where it mainly focused on pipe born water project for house hold consumption and in Badulla farmers were not involved in any NGO activity in the study area.

\subsubsection{Physical Capital}

Availability and mode of transportation in the rural farming areas plays key role in rural economy (Holden, 1998). Hence, analysis of physical capital involved assessment of possession of different transportation means. Different type of vehicles, including bicycles, motor bicycles, three weelers, tractors, trucks and cars were possessed by the MSTH, but neither of them used animal drafted vehicles. Bicycles and motor bicycles were common among all the four categories in two districts, they use it as transportation and carrying goods and bicycle usage was significantly lower among LLH in both districts( table 07). Usage of tractors were extremely lower than trucks and it was higher among LLH in both districts, which they used as a dual purpose uses like human and material transportation. Car usage is extremely luxurious and used by the LLH in two districts where Matara has the higher value, $0.6 \%$ than $0.2 \%$ Badulla, results the comparatively better road network in the district (Table 6).

Table 6. Physical capital of MSTH

\begin{tabular}{lcccccccc}
\hline \multirow{2}{*}{ physical capital } & \multicolumn{3}{c}{ Matara District } & \multicolumn{4}{c}{ Badulla District } \\
\cline { 2 - 9 } & VSLH & SLH & MLH & LLH & VSLH & SLH & MLH & LLH \\
\hline Bicycle & 0.5 & 0.5 & 0.4 & 0.2 & 0.5 & 0.5 & 0.6 & 0.2 \\
Motor bicycle & 0.4 & 0.8 & 0.6 & 0.6 & 0.5 & 0.8 & 0.6 & 0.6 \\
Three wheelers & 0.06 & 0.2 & 0.2 & 0 & 0.1 & 0.1 & 0.2 & 0.1 \\
Tractors & 0 & 0 & 0 & 0.2 & 0 & 0.1 & 0 & 0.1 \\
Trucks & 0.1 & 0.1 & 0.4 & 0.8 & 0 & 0.1 & 0.2 & 0.9 \\
Cars & 0.03 & 0 & 0 & 0.6 & 0 & 0 & 0 & 0.2 \\
\hline
\end{tabular}

\subsection{Futurity of Tea Production Based Livelihood Strategy}

Owing to the less productivity and profitability of the tea farming livelihood strategies, most of the STH are in view that they should look for other alternative livelihood strategy. Especially the MLH and LLH of Matara district and SLH and LLH of Badulla district were in agreement with the idea that it is proving low benefit and they need another option (Table 7). The perception of these category of farmers is also in line with the outcome from the livelihood analysis in the previous section. For MLH and LLH in Matara, for example, only $31 \%$ and $8 \%$ of their income are obtained from tea as compared to the $45 \%$ and $52 \%$ of VSLH and SLH respectively (Table 3). Moreover, owing to small number of family members and also low family member contribution (Table 4), they have to utilize hired labor that increases the cost of tea production and hence reduce its profitability.

Consequently, farmers are forced to abandon portion of all of their tea production land, exacerbating the already exited social (poverty) and environmental (soil erosion, land degradation etc.) problems. Overall, the prominent reason for farmers leaving portion of their land uncultivated (Table 2) are poor natural capital (unproductivity of land, slope of land), low financial return (low profit from the land) and lack of human capital (difficult to find labor to manage the land) and problem of dying out of the plants. Among these, unproductive and eroded land as well as dying of plants were very important factors of VSLL of Matara district while the latter being vital for all categories of Badulla as well as SLH and LLH of Matra district.

Labor shortage is another important factor forcing farmers to leave their farm uncultivated. It is particularly important for MLH of Matara and LLH of Badulla. Labor shortage, however, is found to be less important problem for the VSLH in both district (Table 3). This is because smaller size farmers can efficiently use their family labor as has also been witness by other researches such as Basnayake et al. (2002) and Eastwood,et al. (2010). Overall, for MSTH, tea farming seemed to be compatible livelihood strategy only for VSLH, farmers with land area less than $1 \mathrm{ha}$, as compared to the other land categories, albeit all categories would seem to prefer shifting to other livelihood strategy, if they get the opportunity to do so. 
Table 7. MSTH's general attitude about tea production based livelihood strategy

\begin{tabular}{lcccccccc}
\hline Perception & \multicolumn{4}{c}{ Matara District } & \multicolumn{3}{c}{ Badulla District } \\
\cline { 2 - 9 } & VSLH & SLH & MLH & LLH & VSLH & SLH & MLH LLH \\
\hline Generate low profit (High COP, Input prize) & 3.5 & 3 & 3.8 & 4.4 & 3.3 & 3.8 & 3.2 & 3.7 \\
Have to find another alternative & 2.8 & 2.6 & 4 & 4.2 & 3 & 3 & 3.2 & 3.9 \\
\hline
\end{tabular}

\section{Conclusion and Policy Implication}

This paper explores livelihood capitals of Marginal Small Tea Holder farmers (MSTH) and futurity of tea based livelihood strategies for this category of farmers in Matara and Badulla districts, two districts representing the upper and lower tea production areas of the country respectively. The average landholding ranged from $0.7 \mathrm{ha}$ for VSLH in Matara to 16ha for LLH in Badulla and the percentage of uncultivated land from 7\% for MLH in Badulla to $30 \%$ for LLH. The major reason for having uncultivated were un-productivity and slope of the farming land, low profitability, labor shortage and dying of tea plants. The income generation from Tea crop was found to have reciprocal relationship with size of land. Matara, the district with relatively small size of tea farmland had generated large proportion of income from tea production. Within district too, the VSLH and SLH were found to generate large proportion of their income from tea crop production compared to the MLH and LLH. Although the human capital was found to be good for all, formal education was found to contribute negatively to household member's contribution for tea production. With the fear of being recognized by peers at school of their household role as tea farmer, the educated members were found to be reluctant to help their family in the tea farm activities. Important livelihood capitals, which mostly is neglected in suitable livelihood approach, but found to be salient in this study are elevation and weather. These two, categorized under natural capital in this study, were found to play important role in affecting the livelihood outcome from tea production.

Despite its important contribution for household income for most of the samples households, famers were found to be pessimistic to continue tea production and in favor of alternative livelihoods. The high input requirement of this livelihood strategy together with the low productivity of land and the weather condition seemed to contribute for their attitude. One possible alternative for farmers is to convert the Tea plantation in to fuelwood plantation. Doing so will minimize the cost of production that is discouraging the farmers to continue tea farming. Tree species such as Gliricidia septum and Calliandra calothrysus that are important source of fuel wood have been growing well in the existing topography and weather condition in the marginal lands as witnessed by current dominance in the landscape. Hence they can be considered for fuelwood planation establishment. In addition to logs from these trees when they reach to harvestable age, twigs and branches from lopping and pruning during their development can also serve as an important source of fuelwood for subsistence and commercial uses. With appropriate advertisement and negotiation, these plantations can also be incorporated in to Payment for Environment Service (PES) for their local (such as flood and soil erosion protection) and global (carbon sequestration) environmental services to generate intermediate income for local people. Market for the fuelwood will also continue to be promising considering the existing severe shortage of fuelwood, especially in the tea production industry.

In order to facilitate the aforementioned land use conversion that will benefit both the environment and local people, future detail participatory feasibility studies are vital. It is also crucial to evaluate the existing policy environment such as Land policy, Forest policy, Environmental policy, Agriculture policy and Energy policy of the country with respect to their implications on farmers' decision to combine their tea based livelihood with that of fuelwood production.

\section{Acknowledgments}

The authors thank and acknowledge partial financial support from Grants-in-Aid for Scientific Research (A) supported by the Government of Japan (No. 24248026, Project leader: Makoto Inoue). The finding, however, does not represent the views of the Japanese Government.

\section{References}

Amerasinghe,Y. R. (1993). Recent Trends in Employment and Productivity in the Plantation Sector of Sri Lanka: with special reference to the Tea Sector. ILO (pp 3-25) Geneva, Switzerland.

Barret, H. R., Browne, A. W., Harris, P. J. C., \& Cadoret, K. (2002). Organic certification and the UK market: organic imports from developing countries. Food policy, 27(4), 301-318. http://dx.doi.org/10.1016/S0306 -9192(02)00036-2 
Barrett, H. R., Browne, A. W., Harris, P. J. C., \& Cadoret, K. (2001). Smallholder farmers and organic certification: Accessing the EU Market from the developing world. Biological Agriculture \& Horticulture: An International Journal for Sustainable Production Systems, 19(2), 183-199. http://dx.doi.org/10.1080/ 01448765.2001.9754920

Basnayake, B. M. J. K., \& Gunaratne, L. H. P. (2002). Estimation of Technical Efficiency and Its Determinants in the Tea Small Holdings Sector in Mid Country Wet zone of Sri Lanka. Sri Lankan Journal of Agricultural Economics, 4, 21-37. http://dx.doi.org/10.4038/sjae.v4i0.3488

Baumann, P. (2002). Improving access to natural resources for the rural poor: A critical analysis of central concepts and emerging trends from a sustainable livelihoods perspective. FAO LSP Working Paper No. 1. Rome.

Bebbington, A. (1999). Capitals and capabilities: a framework for analyzing peasant viability, rural livelihoods and poverty. World Development, 27(12), 2012-44. http://dx.doi.org/10.1016/S0305-750X(99)00104-7

Brocklesby, M. A., \& Fisher, E. (2003). Community development in sustainable livelihood approaches-an introduction. Community Development Journal, 38(3), 185-198. http://dx.doi.org/doi: 10.1093/cdj/38.3.185

De Jong, R., Ariyaratne, M. G., \& Ibrahim, M. N. M. (1999). Performance of dairy farming on abandoned marginal tea lands in the mid country of Sri Lanka. Tropical Agricultural Research and Extension, 2(1), $55-66$.

De Silva, K M. (1981). A history of Sri Lanka. Berkeley, CA: University of California Press.

De, P. K., \& Ratha, D. (2012). Impact of remittances on household income, asset and human capital: Evidence from Sri Lanka. Migration and Development, 1, 163-179. http://dx.doi.org/10.1080/21632324.2012.719348

DFID. (1999). Sustainable livelihoods guidance sheets. Department for International Development, London

Dissanayake, D. R. R. W, Udugama J. M. M., \& Jayasinghe-Mudalige, U. K. (2013). Development of an Alternative Microfinance Scheme to finance in the Tea Small Holding sector: A success story. Journal of Food and Agriculture, 3(1-2), 31-40. http://dx.doi.org/10.4038/jfa.v3i1-2.5168

FAO. (2012). Report of the Intercessional Session of the IGG on Tea. FAO: Colombo.

Forestry Sector Master Plan [FSMP]. (1995). Sri Lanka Forestry Sector Master Plan. Forestry Planning Unit, Ministry of Agriculture, Lands and Forestry.

Ganewatta, G., \& Edwards, G. W. (2000). The Sri Lanka Tea Industry: Economic Issues and Government Policies. 44th Annual Conference of Australian Agricultural and Resources Economics Society, University of Sydney, Australia, 23-25 January 2000.

Herath, D., \& Weersink, A. (2009). From plantations to smallholder production: the role of policy in the reorganization of the Sri Lankan tea sector. World Development, 37(11), 1759-1772. http://dx.doi.org/10. 1016/j.worlddev.2008.08.028.

Jayamanne V. S., Wijeratne, M., \& Wijayaratna, C. M. (2002). Adoptability of New Technology in the smallholdings Tea Sector. Journal of Agriculture and Rural Development in the Tropics and Subtropics, 103(2), 125-131.

Korf, B., \& Oughton, E. (2006). Rethinking the European countryside - can we learn from the South? Journal of Rural Studies, 22, 278-28. http://dx.doi.org/10.1016/j.jrurstud.2005.09.005

Markelova, H., \& Mwangi, E. (2010). Collective action for smallholder market access: evidence and implications for Africa. Review of policy research, 27(5), 621-640. http://dx.doi.org/10.1111/j.1541-1338.2010.00462.x

Mendis, P. (1992). Human environment and spatial relationship in agricultural production: The case study of Sri Lanka and other tea producing countries. Peter Lang Publishing: NY.

Mohammed, A. J. (2014). Decentralization, Forest and Poverty: Framework and Case Studies from Ethiopia. Nova Science Publishers: NY.

Mohammed, A. J., \& Inoue, M. (2013). Forest-dependent communities' livelihood in decentralized forest governance policy epoch: case study from West Shoa zone, Ethiopia. Journal of Natural Resource Policy Research, 5(1), 49-66. http://dx.doi.org/10.1080/19390459.2013.797153

Mohammed, A. J., \& Inoue, M. (2014). Linking outputs and outcomes from devolved forest governance using a Modified Actor-Power-Accountability Framework (MAPAF): Case study from Chilimo forest, Ethiopia. Forest Policy and Economics, 39, 21-31. http://dx.doi.org/10.1016/j.forpol.2013.11.005 
MungaI, D. N., Ong, C. K., Kiteme, B., Elkaduwa, W., \& Sakthivadivel, R. (2004). Lessons from two long-term hydrological studies in Kenya and Sri Lanka. Agriculture, Ecosystem and Environment, 104(1), 135-143. http://dx.doi.org/10.1016/j.agee.2004.01.011

Samaraweera, I. (1982). Land Reform in Sri Lanka. Third Word Legal Studies (Vol.1, Article 7).

Scoones, I. (1998). Sustainable rural livelihoods: a framework for analysis (Working Paper 72). Brighton: Institute for Development Studies.

Sherbinin, A., Vanwey, L. K., McSweeney, K., Aggarawal, R., Barbieri, A., Henry, S., \& Walker,R. (2008). Rural household demographics, livelihoods and the environment. Global Environment Change, 18, 38-53. http://dx.doi.org/10.1016/j.gloenvcha.2007.05.005

Sivapalan.P, Kulasegaram, S., \& Kathiravetpillai, A. (2006). The way of cultivating tea: Hand book on tea. Tea Research Institute: Thalawakele.

Wenzlhuemer, R. (2008). From Coffee to Tea Cultivation in Ceylon, 1880-1900: An Economic and Social History. Brill Academic Pub: Boston.

Yang, C., Shropshire, G. J., \& Peterson, C. L. (1997). Measurement of ground slope and aspect using two inclinometers and GPS. Transactions of the ASAE, 40, 1769-1776.

Ziyad-Mohamed, M. T., \&Zoyas, A. K. N. (2006). Current status and future research focus of tea in Sri Lanka. The Journal of Agricultural Sciences, 2(2), 32-42.

\section{Copyrights}

Copyright for this article is retained by the author(s), with first publication rights granted to the journal.

This is an open-access article distributed under the terms and conditions of the Creative Commons Attribution license (http://creativecommons.org/licenses/by/3.0/). 